\title{
Forced Out-Migration from Hill Regions and Return Migration During the Pandemic: Evidence from Uttarakhand
}

\author{
Ishwar Awasthi ${ }^{1} \cdot$ Balwant Singh Mehta $^{1}$
}

Accepted: 21 September 2020 / Published online: 12 November 2020

(c) Indian Society of Labour Economics 2020

\begin{abstract}
This paper deals with out-migration which has been a common phenomenon in the hill regions and is closely related to their socio-economic and cultural patterns. In particular, male-specific out-migration has been a sustained tradition from the hill districts of Uttarakhand. The people have been migrating not just for seeking diverse avenues of employment, but also for accessing better educational and health opportunities. As per 2011 Census, the overall population growth rate in the state was $1.7 \%$ with huge differentials in the hill and plain districts. Hill districts witnessed one-fourth growth $(0.7 \%)$ of the population compared to that of plain districts $(2.8 \%)$ suggestive of huge out-migration from these (hill) districts of the state. The important thing to note is that the nature and patterns of out-migration have now paved the way from long-term to permanent out-migration. Also, the lack of employment opportunities is creating distress out-migration to destinations within or outside the state, which has become a major cause of concern. The COVID-19 pandemic has impacted the most short-term migrants who returned to their villages in desperation resulting in despondency and distress. In this context, the paper explores the factors of distress migration by analysing the data from a quick survey of 323 return migrants carried out in June 2020 to understand their employment and livelihood profile, reasons for their return to native places, coping mechanism and future plans. The findings reveal that due to lack of livelihood opportunities in their place of origin, most of them would eventually like to return to their destination places in the future to eke out their living. From a policy point of view, enhancing the economic base and livelihood opportunities by focusing on niche activities with improved provisioning of educational and health infrastructure and services can eventually help restrict out-migration from Uttarakhand.
\end{abstract}

Keywords Return migration - Covid-19 pandemic $\cdot$ Ghost villages $\cdot$ Remittance . Livelihood · Coping mechanism

Ishwar Awasthi

icawasthi@gmail.com

Extended author information available on the last page of the article 


\section{Introduction}

There has been a change in perspective on the relationship between migration and development. Early migration and development links clearly showed development positivism during the 1950s and 1960s but the shift later drifted around structuralist approach during 1970s and 1980s with a pessimistic outlook. However, the swing moved towards livelihood approach in a broader developmental paradigm during the 1990s, as opposed to structuralist construct.

Later, since 2000 the edifice of empirical work largely supported the migration and development formulations (de Haas 2008). Different aspects of migration have been studied within varied theoretical constructs. The individualistic approach of migration which is credited to Todaro (1969) and extension of this approach to household approach (Stark 1980, 1991) considered migration is essentially an economic phenomenon and has positive consequences. The structural formulation of migration credited to scholars, like Safa, Mc Gee, Standing and Breman, analysed labour mobility within the Marxian framework (cited from De Haan 1999). This school of thought regarded labour mobility as an exploitative mechanism of the capitalistic framework with negative consequences both at destination and at source areas.

These migration theories are closely linked with the social, economic and cultural transactions that have profound implications on migrants and their families. Social transactions can be looked from the perspective of social capital that includes the resource endowments of one's associates and the social relationship (Portes 1998; Ioannides and Datcher Loury 2004). It has been well documented that the job search route through informal channels, such as friends and relatives and familial ties, play an important role in migration process (Ioannides and Datcher Loury 2004). Even non-familial ties are emerging as an important source for accessing jobs in urban labour markets (Mitra, 2010). It has been also noted that migrant workers from poverty-stricken households are more likely to use informal job search routes (Stark 1995; Mitra 2004, 2010). As regards economic gains are concerned, the theories explicitly argue that expected gains from out-migration are substantially higher than the prevailing wages or incomes at the place of origin.

The backward economies with peculiar regional specificities (e.g. hill/mountain regions) have shown strong patterns of out-migration to lowland or flat land areas caused primarily by the differing opportunities or amenities between the two distinct locations and more so carried out as a coping mechanism. Although many such backward areas have certain resource advantages in terms of niche products, the resources cannot be used intensively due to peculiar features that keep the region at a disadvantaged position. There are, thus, obvious limitations both in the Lewisian theory and in export-led theory, which suggests venting surplus to the backward economies through exporting labour and trade theory through exporting staple resources.

Historically, the movement of people takes place primarily because of lag in the development of different regions and often people migrate from backward 
region to relatively developed region for better employment and livelihood opportunities. The large movement of labour from less developed rural areas to more developed urban centres is the testimony of unequal development trajectories. Similarly, the hill areas or mountain regions are at a more precarious position compared to plain or lowland areas in terms of economic opportunities and infrastructure development. These specificities often expose the people in these fragile regions to food shortages and other locational disadvantages.

People of mountain areas depend on subsistence farming, livestock and income generation from small-scale trade and wage activities for their livelihood (International Centre for Integrated Mountain Development (ICIMOD) 2017). The dependence on subsistence economy and lack of sufficient local employment opportunities force a large number of adult males to out-migrate from mountain regions to other areas in search of livelihood (Maithani 1996; ICIMOD 2011). Therefore, migration from hill or mountain region is common and core livelihood strategy for most people in the Hindu Kush Himalayan Region (HKH) comprising eight countries, namely Afghanistan, Bangladesh, Bhutan, China, India, Myanmar, Nepal and Pakistan, which forms either part or full mountain or hill region. It is estimated that more than $65 \%$ of the 210 million people in the $\mathrm{HKH}$ region suffer from malnutrition, perpetual food insecurity, and degradation of natural resources, and frequent disasters that threaten the livelihood security of the people in the region (Brigitte and Michael 2009). It is estimated that close to $15 \%$ of the world's total migrants come from the HKH countries. India, China, Bangladesh, and Pakistan are among the largest migrant-sending countries in the world (Brigitte and Michael 2009). Migration is increasingly perceived as an effective strategy for livelihood that can help alleviation of poverty in mountain areas in particular and other under-developed areas in general.

However, the unprecedented COVID-19 pandemic has entailed enormous difficulties and brought multiple hardships to migrant workers all over the world, including India. The job losses and fear of virus pushed millions of migrant in a panic situation and forced them to return to their homes under distress to farflung areas in rural areas. The visuals of miseries and desperate situations that migrants encountered while returning to their homes were seen across railway stations, bus stations, highways and on the roads in different parts of India. Most migrants in the country come from under-developed areas such as Uttar Pradesh, Bihar, Rajasthan, Madhya Pradesh, Odisha, Jharkhand and West Bengal and also from the hill state of Uttarakhand. It is estimated that about 12 million migrants returned to their places of origin during the initial period of the pandemic (Indian Express, June 8, 2020) mainly to these states. The number of migrant workers who returned to their homes in Uttarakhand during the pandemic was estimated at about 2.15 lakh. The returning migrants had many different tales regarding sufferings distress and pains, loss of livelihood and income, nature of jobs at destination places, duration of migration, family and government support, reasons to return, future plan, etc. Hence, there is a need to understand the several interlinked issues of out-migration in such a pandemic situation while formulating policies and strategies to arrest such distress form of migration in future. In this 
background, this paper explores the nature of out-migration from hill regions and impact of COVID-19 on lives of migrants by taking a case of Uttarakhand.

This paper is mainly based on a primary survey conducted among over 300 migrants who returned to Uttarakhand in the aftermath of the COVID-19 pandemic. In addition, secondary information from 'Human Development Report-Uttarakhand (HDR-UK) 2019' prepared by the Institute for Human Development and other government data such as Census of India, National Sample Survey (NSS) and available literature on the out-migration for hill regions and Uttarakhand has also been consulted. The paper is structured into five sections. The first section discusses the migration in general and in the context of mountain economies, the second section focuses on an overview of Uttarakhand, and third section presents the outmigration from the mountain state. The fourth section provides empirical evidence based on the recent pandemic that saw a huge number of migrants from the Uttarakhand returning to the hill districts. The fifth section analyses the results of logistic regression to examine the important factors that affect the probability of a person to out-migrate from the place of their origin. The final section details out pragmatic measures to restrict distress-driven out-migration.

\section{Uttarakhand: An Overview}

The state of Uttarakhand was created in November 2000 and its development path since its formation has been one of reasonably high economic growth. Economic growth in the state has been reported 9.8\% 7.8\% 6.9\% (Base Year, 2011-12) during 2016-17, 2017-18 and 2018-19 which is higher than the All India (7.1\%, 7.2\% and $6.8 \%$, respectively). However, the growth rate plummeted to 4.3 percent in 2019-20 which is similar to that of all India (4.2 percent). The secondary sector dominates in the state economy, and contribute almost half (49\%) in its Gross State Domestic Product (GSDP) in 2019-20, with 37\% share of the manufacturing sector. The sectoral GSDP (current prices) for the primary, secondary, manufacturing and tertiary sectors growth is estimated to be $4.1 \%, 5.5 \%, 5.4 \%$ and $8.5 \%$, respectively for 2019-20 (PE). Per capita income of the state estimated (current prices) for the year 2019-20 and 2018-19 is Rs. 2,02,895 Rs. 1,91,450, respectively, (Government of Uttarakhand 2019-20), which was substantially more than All India average of Rs. $1,35,050$ in 2019-20.

However, the growth of secondary and tertiary sectors in the state has been mainly focused in the three plain districts, leaving the ten hill districts lagging behind. While the plain districts have had a large proportion of economic opportunities, the residents of the hill districts have predominantly been earning their livelihoods from agriculture and agricultural labour. This lopsided development has led to large out-migration from the hill areas towards the plains. Data from the Population Census 2011 reveal slow growth of population for the hill districts of the state, with Almora and Pauri Garhwal showing an absolute decline in population over the decade 2001 to 2011 which is a clear evidence for out-migration in large numbers (Mamgain and Reddy 2015). Lack of economic opportunities and increasing pressures on the local economy have been cited as the two possible reasons for 
such out-migration. Migration has been a common phenomenon in the hill region of Uttarakhand and closely related to its socio-economic and cultural patterns. Studies on migration for Uttarakhand point towards huge and increasing male out-migration from the region (Khanka 1988; Bora 1996, Awasthi 2012).

\section{Out-Migration from Uttarakhand}

Huge out-migration from the hill districts is palpably clear from the district level population growth between 2001 and 2011. Out of 13 districts, 10 districts are hill districts and three are plain districts. Hill districts recorded very low population growth at $0.7 \%$, and in fact the two hill districts, namely Almora and Pauri Garhwal, recorded an absolute decline in population in 2011 over 2001. Other hill districts, namely Pithoragarh, Rudraprayag, Bageshwar, Chamoli and Tehri Garhwal, recorded around 5\% growth and Uttarakashi registered about 12\%, Champawat $14 \%$ and Nainital (which is partly hill and partly plain) reported $25 \%$ decadal growth, while three plain districts (Dehradun, Haridwar and Udham Singh Nagar) recorded over 30\% decadal growth. There were 16,793 census villages in 2011, of which 1053 had no inhabitants and another 405 had a population of less than 10, clearly signifying high levels of out-migration from the hill districts.

What is important to note is that the nature, causes, patterns and consequences of out-migration have changed over time. In the past, the primary reason for longterm male out-migration was for jobs and earning a living, with strong linkages to one's home, often called the "money order economy" (Bora 1996). With development taking root in the hill regions, long-term migration has become permanent outmigration leading to many villages transforming into ghost villages in these areas. Migration not just for employment but also being resorted for better educational opportunities has led to lost or no linkages with the places of origin. As per the Census of India, the major reasons for migration from the hill districts were work/ employment/business, while in the plain districts the prime reason is marriage followed by work/employment/business.

It is a well-known fact that huge out-migration within and out of Uttarakhand has been taking place over many decades. However, the earlier flow of out-migration was limited to males for long term with strong linkages to the place of origin. However, the nature of out-flow has changed over the years and out-migration has been taking place with family members that has understandable implications for the place of origin and is creating a sort of ghost villages (Uttarakhand Migration Commission 2019). The basic reason for the high rate of out-migration from the hill districts is attributed to lack of income opportunities, lack of accessibility of good education and health care facilities. Farming, which used to be the main occupation for hill people, has become increasingly unsustainable and uneconomical due to lack of irrigation facilities and the erratic weather pattern.

Some micro-level studies in the Uttarakhand hill areas report that $42 \%$ to $57 \%$ of households have at least one out-migrant (Khanka 1988; Bora 1986, 1996). Yet another study finds that $48 \%$ of households reported out-migration, $34 \%$ reported long-term migration, $16 \%$ reported permanent migration, and $4 \%$ reported 
Table 1 Migration status of household (\%), 2017

\begin{tabular}{llllll}
\hline Area & Non-migrants & $\begin{array}{l}\text { Daily } \\
\text { commut- } \\
\text { ers }\end{array}$ & $\begin{array}{l}\text { Short-term } \\
\text { migrants }\end{array}$ & $\begin{array}{l}\text { Long-term } \\
\text { migrants }\end{array}$ & Total \\
\hline Rural & & & & & \\
Hill & 60.7 & 0.8 & 3.2 & 35.3 & 100.0 \\
Plain & 95.2 & 0.3 & 1.9 & 2.6 & 100.0 \\
Total & 66.5 & 0.7 & 3.0 & 29.8 & 100.0 \\
Urban & & & & & \\
Hill & 85.5 & 0.4 & 2.6 & 11.5 & 100.0 \\
Plain & 93.7 & 0.1 & 0.9 & 5.3 & 100.0 \\
Total & 88.9 & 0.3 & 1.9 & 8.9 & 100.0 \\
Total & & & & & \\
Hill & 65.0 & 0.7 & 3.1 & 31.2 & 100.0 \\
Plain & 94.5 & 0.2 & 1.5 & 3.8 & 100.0 \\
Total & 71.6 & 0.6 & 2.7 & 25.1 & 100.0 \\
\hline
\end{tabular}

Source: HDR-UK (2019, p. 135)

short-term migration (Awasthi 2010). The HDR-UK (2019) found that close to a tenth $(8 \%)$ of the sample population in the state was out-migrant (short and long term) with rural migrants recording a much higher proportion (9\%) as compared to urban migrants (3\%). Short-term migration accounted for about $2.7 \%$ of the population and the hill districts reported $3.1 \%$ and the plain districts $1.5 \%$. The magnitude of households that have at least one migrant (short term or long term) was $28 \%$, implying that almost one in every three households had a migrant. However, the magnitude differs significantly between the hill and plain districts. In the hill districts, the proportion of households having at least one migrant was $34 \%$, while for the plain districts it was $5 \%$. Hill districts noted higher rates of long-term out-migration compared to plain districts. Rural households, having one or more out-migrants, recorded more than double the out-migration rate compared to urban households (52\% and $24 \%$, respectively). Clearly, the hill areas report a higher share of households having at least one migrant in both the rural and urban areas. The proportion accounts for about $39 \%$ and $14 \%$, respectively, while in the plain areas their corresponding size was $4.5 \%$ and 6\%, respectively (Table 1). Across districts, hill district, Rudraprayag, accounted close to half the households (48\%) having long-term outmigrants. The other hill districts such as Almora, Bageshwar, Chamoli, Champawat and Pithoragarh reported over one-third of their households as having long-term out-migrants (HDR-UK 2019).

With better means of transport, commuting has emerged as an alternative to migration. ${ }^{1}$ Tables 1 and 2, therefore, include information about both commuters and migrants. The magnitude of long-term migration is the highest followed by

\footnotetext{
1 As per Census of India, migrants are those who are enumerated at village/town other than their place of birth/place of last residence. Commuters are thus not enumerated as migrants.
} 
Table 2 Migration status by location and social groups

\begin{tabular}{|c|c|c|c|c|}
\hline & Daily commuters & $\begin{array}{l}\text { Short- } \\
\text { term } \\
\text { migrant }\end{array}$ & $\begin{array}{l}\text { Long- } \\
\text { term } \\
\text { migrant }\end{array}$ & Total HH \\
\hline \multicolumn{5}{|l|}{ Hill/plain } \\
\hline Hill & 2.5 & 9.2 & 88.3 & 380,666 \\
\hline Plain & 3.5 & 25.9 & 70.6 & 72,599 \\
\hline Total & 2.6 & 11.9 & 85.5 & 453,265 \\
\hline \multicolumn{5}{|c|}{ Quintile urban } \\
\hline Quintiles 1 & 14.0 & 6.8 & 79.2 & 3282 \\
\hline Quintiles 2 & 0.0 & 20.5 & 79.5 & 6693 \\
\hline Quintiles 3 & 2.5 & 26.6 & 70.9 & 8570 \\
\hline Quintiles 4 & 1.5 & 21.6 & 76.9 & 18,960 \\
\hline Quintiles 5 & 2.5 & 8.8 & 88.7 & 30,837 \\
\hline \multicolumn{5}{|c|}{ Quintile rural } \\
\hline Quintiles 1 & 4.3 & 9.6 & 86.1 & 46,034 \\
\hline Quintiles 2 & 3.8 & 11.4 & 84.8 & 60,471 \\
\hline Quintiles 3 & 2.6 & 9.0 & 88.4 & 82,400 \\
\hline Quintiles 4 & 2.2 & 13.6 & 84.2 & 93,611 \\
\hline Quintiles 5 & 1.6 & 11.4 & 87.0 & 102,407 \\
\hline \multicolumn{5}{|c|}{ Social group } \\
\hline $\mathrm{SC}$ & 4.0 & 11.9 & 84.1 & 78,096 \\
\hline ST & 0.0 & 14.4 & 85.6 & 12,349 \\
\hline $\mathrm{OBC}$ & 6.3 & 14.5 & 79.2 & 45,719 \\
\hline General & 1.8 & 11.4 & 86.8 & 317,101 \\
\hline
\end{tabular}

Source: HDR-UK (2019, p. 137)

short-term and daily commuting. The intensity of long-term migrating households is much higher in the hill area compared to that of plain area. Conversely, in the case of short-term and daily commuting households, the share is higher in the plain area. This pattern appears to be true for all income quintile groups except the lowest quintile income group in the urban area where daily commuting households outstrip short-term migrating households. The disadvantaged social group migrating households (scheduled caste (SC), scheduled tribe (ST) and other backward class (OBC)) have a higher proportion of daily commuters probably due to their low economic base that discourages them to go for long-term migration. Also, the high cost of migration necessitates some foothold in the labour market which requires requisite education and skill levels to compete in the urban labour market. Evidently, longterm migrating households noticeably dominate in all income quintile groups that clearly indicate the higher probability of getting employment and better wages and incomes compared to short-term migrants and daily commuters (Table 2). There is no major variation among long-term migrating households across social groups. Noticeably, the proportion of the long-term migrating households is the highest among all social groups with little variations (HDR-UK 2019). 
The rural-urban disparity was also stark with more than a third of the households in rural hill areas having at least one migrant vis-à-vis $11 \%$ in urban areas. Outmigration in Uttarakhand can primarily be attributed to a combination of push and pull factors like the lack of employment, low income, subsistence agriculture, better opportunities for employment and children's education, etc. 'Search for employment' is the single major reason for out-migration, which clearly showcases the shrinking job opportunities in the state. This factor shows large inter-district variations as well.

Remittances have been playing an important role in the individual household as well as the village economy, particularly in the hill districts. Poor households depend considerably on remittance that forms an important source of their income. It helps to accelerate the development of village economy as remittance income is also invested in various farm and non-farm activities. However, the migration studies on both the aspects - the volume of remittance and its impact on the village economy-do not provide any demonstrative evidence (Stark 1980, 1991; Lipton 1980). Nevertheless, the literature on migration argues that remittance is an important means for poor households that help to diversify their incomes and ensure their survival (Harris 1991; Ellis 2000).

Migrants are a vulnerable and unprotected lot and often face discrimination in the labour market, more particularly the seasonal and short-term migrants. They are subject to social and economic discrimination and are often exploited in terms of low wages and precarious work conditions. This exploitation often leads to segmented and informalised labour markets that helps faster accumulation of capital at the cost of intensive exploitation of labour (Srivastava 2019). In the times of crisis such as current pandemic situation, the migrants face a double whammy pushing them into poverty - the brunt of job losses, and the compulsion to reverse migrate, although livelihood opportunities are limited at their place of return.

This migrant crisis has evoked several questions, such as: Why did the lockdown prompt the migrants to leave the cities? How did the COVID-19 shock impact the livelihoods? What is the nature of assistance received from the Government and other civil society organisations? What coping mechanisms are being adopted by the return migrants and what are their future plans in the pandemic situation? In order to address these questions, a reflective primary investigation was conducted among the return migrants and its results are discussed in the following section.

\section{Return Migrants During the Pandemic: Survey Findings}

To assess the impact of the pandemic on return migrants, a telephonic survey was conducted in the hill districts of the state, between May 7 and June 7, 2020. Return migrants' details were collected from the district nodal officer and District Magistrate's office. In all, 323 return migrants were interviewed telephonically by the investigators. The survey was carried out in both the administrative regions of the state, namely Kumaon and Garhwal with 223 and 100 respondents, respectively. The information was collected on different aspects like: profile of individual return migrants in terms of age, sex, education, social groups; duration of migration and 
destination centres of return migrants; employment and remuneration; difficulties encountered during the lockdown period; assistance received; coping mechanisms; future plans, etc. The questions were short and focused, and no detailed inquiry could be possible through a telephonic survey. The sample of return migrants was selected through purposive or snowball/reference method. Hence, the survey results may not necessarily be generalised, yet the findings throw some important insights about situation of the migrants in the current pandemic situation, which are pivotal for formulating effective strategies pertaining to migration from hill regions.

\subsection{Respondents Profile}

Out of a total sample of 323 return migrants, the majority were males (90.4\%) and only $9.6 \%$ were females. Nearly $70 \%$ (69\%) respondents were youth (15-29 years) followed by $28.9 \%$ of middle-aged (30-49 years), with the minuscule proportion of $50-59$ years and 60 plus (2.5\%). These findings corroborate evidences provided by previous field survey-based studies that returns to migration are supposedly higher for younger age migrants (Awasthi 2012; Mamgain and Reddy 2015). Across social groups, General Caste dominates (58\%) followed by SC (29\%), OBC (10\%) and ST $(3 \%)$. The educational qualification of respondents shows that over half $(58 \%)$ of them had higher secondary and above education and one-fifth (20\%) were graduates. This reveals that the overwhelming majority of return migrants were youth and males, belonged to the general caste and had significantly high level of educational qualification, which also corroborate the findings of several previous studies on the nature of out-migration from the state.

\subsection{Characteristics of Migrant Returnees}

Over one-third (36\%) of the respondents reported having migrated within the state, i.e. mainly to plain areas, while others migrated to other states like Maharashtra (39\%), Delhi \& National Capital Region (NCR) (10\%), Rajasthan (7\%) and a few others across the country (8\%). Further, the prominent destination centres were Mumbai (Maharashtra); Haridwar, Udham Singh Nagar and Dehradun (Uttarakhand); Jaipur, Bikaner and Kota (Rajasthan); and Noida, Ghaziabad and Gurugram (NCR Delhi). All these destinations are considered to be attractive to migrants primarily because they provided better employment opportunities. Majority of the migrants $(62 \%)$ returned alone, while others returned along with family members $(19 \%)$, relatives $(13 \%)$ and friends $(5 \%)$. This also reflects the migration pattern from the state, where the majority of people migrate to the city either alone or with family members/relatives.

It has been observed that majority of those who returned were those who migrated within the last few years. Out of total respondents, $41 \%$ had migrated to their destinations within 1 year; $23 \%$ within 2 years; $18 \%$ between 2 and 5 years period; and rest above 5 years $(17 \%)$. Others who might have either permanently settled at their destinations or may have had limited connection with their native places due to several reasons figured very less among the returnees. One of the prominent 
reasons for the rising number of ghost villages is the huge out-migration from hill districts of the state due to lack of livelihood opportunities and other infrastructural facilities (HDR-UK 2019).

\subsection{Employment and Livelihood}

Employment and livelihood are the most important factors that are initiating and perpetuating migration flows from hill regions. Engagement in multiple sources of livelihoods is most common not only among poor but relatively well-off households in order to augment their incomes. Two different processes seem to work simultaneously: first, as a deliberate household strategy to enhance income as an involuntary response to a crisis situation (Stark 1991); and second, to seize opportunities as a means of accumulation (Davies 1996). In poor regions, people depend on various sources of employment primarily because of sustenance in the absence of any sole option of employment. Multiple economic activities are most pervasive and widespread among different groups of population in the survey areas in Uttarakhand, manifesting symptoms of the backward economy (Awasthi 2012). Out-migration has thus become an important livelihood strategy for the people in the hill districts.

Among the surveyed respondents, majority were salaried workers (81\%) followed by an almost equal proportion of self-employed (10\%) and casual daily wage workers $(9 \%)$. Self-employed migrants were involved mainly in small shops, street vending and petty business activities. The casual daily wagers worked in construction work and in informal transport systems. A large majority of these workers lost their jobs in the wake of the pandemic situation. Although differentiated from casual workers due to monthly engagements and salaries, the salaried returnee workers were in precarious jobs and were found to equally vulnerable. They were mostly engaged as waiters, cooks and clerks at small hotels, restaurants and dhabas; lower staff, housekeeping and security guards, and those working in private companies/ factories and in petty informal jobs. This typically shows the dominance of lowskilled, low-income and informal sector jobs, which are prone to any shock like the current pandemic.

The nature and types of work/activities have a direct relationship with the earning and level of salaries and remuneration. The average salary and earnings reported are quite low. The average income of self-employed was the highest per month among the activity status groups (Rs. 14,500) followed by salaried workers (Rs. 13,241) and daily wage workers (Rs. 10,117). This confirms the high prevalence of low-income activities or jobs among the migrants. As per the Periodic Labour Force Survey (PLFS), 2017-2018 (NSSO 2019), the average monthly income for non-agriculture workers in self-employed activities works out to be Rs. 12,722, for regular workers, and it is the highest at Rs. 16,571 for casual workers. Clearly, the average monthly earnings for salaried migrant workers who were returnees were lower compared to all India average earnings as reported in PLFS. Further, the low earnings or income of the migrants is compounded by their sole earning member status in the family, which makes them more vulnerable. Majority of migrant workers (62\%) reported that they were the sole earning member in their families. 
The above analysis provides much credence to the observed hypothesis that short-term and circular migrant workers are more vulnerable than the long-term and permanently shifted workers in the long-drawn process of out-migration in terms of both the status of employment and earnings.

\subsection{The COVID-19 Shock and Migrant Workers from Uttarakhand}

It is disturbing to note that almost three-fourth (72\%) of migrant workers were not paid by their employers during COVID-19 induced lockdown, which reflect the despondency and livelihood crisis that forced migrant to rush to their native places. This is also reflected from their prominent reasons for returning home as the majority of them reported job losses (63\%) followed by fear of COVID-19 pandemic $(51 \%)$ and pressure from family members $(24 \%)$ to return home. Some followed other relatives who had returned home, indicating the role of emotional and psychological factors.

The return was a horrifying experience to the migrants; thousands were stranded on their way back home with limited support enroute. Transport was completely standstill due to the lockdown, and this forced several migrants to resort to walking back to their homes, with many traversing long distances on foot. This situation continued unabated for many weeks. Subsequently, the governments started making travel arrangements for the migrants to return to their homes. Majority of the respondents returned to their homes by bus/road (72\%) followed by trains (19\%). In some exceptional cases, few of them also reported that they flew down to their native places with help from several individuals and social activists.

\subsection{Assistance from Government, CSO and Employers}

It was widely reported that governments, employers and voluntary and civil society organisations came forward to help the migrant workers by way of providing food, shelter, cash and transportation facilities. In the case of stranded migrants of Uttarakhand, only half of the migrants $(50.5 \%)$ received some form of assistance from the government and voluntary organisations. In the case of government welfare schemes, major benefits received by the migrant workers were in the form of ration $(43 \%)$ either free or subsidised, some benefits $(7 \%)$ were also received from the Pradhan Mantri Garib Kalyan Yojana and the Prime Minister Kisan Samman Nidhi, and nearly $3 \%$ migrants were provided temporary shelter.

It is clear that benefits from the government programmes were not significant in providing the necessary support to the migrants. The reasons reported vary: (i) some of them did not have any knowledge about the welfare schemes; (ii) there was none from the government or civil society organisations who could guide and help to avail benefits, and (iii) most of the benefits were limited to those who have bank accounts as the amounts were to be transferred to their accounts through direct benefit transfer scheme (DBT) mode, whereas many migrants did not have a bank account. The respondents reveal that over three-fourth $(76 \%)$ of them were unaware of the schemes and around one-fifth (18\%) did not have bank accounts. 
Further, one of the reasons for not being able to access the benefits of government schemes was the non-registration of returned migrants with government agencies, as registration is mandatory for availing benefits under many schemes. It was also reported that more than half $(55 \%)$ of the migrants were not registered with the government under the different migrant centred schemes. The non-registration and the consequent ineligibility to obtain the intended benefits under the government schemes further made the situation of the migrants more vulnerable. However, skill mapping of the return migrants has been initiated and it is envisaged that this exercise may provide the basis for evolving employment and livelihood strategies for distressed return migrants.

Even the assistance from the non-governmental organisations (NGOs) and/or civil society organisations (CSOs) was insignificant (16\%). One of the reasons for this inconsequential assistance was the lack of such organisations operating in these regions, and whichever organisations existed, their operations were limited with a low endowment base.

Employers helped their workers in the pandemic situation in several ways, especially in the form of providing advances or payment of their salary/remuneration and cash assistance, albeit the help did not come from a large number of employers. Yet, whatever assistance was provided was timely and necessary. However, such help and assistance were sparse in the case of returned migrants in Uttarakhand, with only $8 \%$ of respondents reporting that they received assistance from their employers, aggravating the vulnerability of many low-end wage workers.

\subsection{Coping Mechanism}

A coping mechanism is a survival strategy to ward off risks associated with livelihood security particularly in catastrophic conditions like flood, disaster, drought, epidemic or conflict situations. Thus, individuals or households, more so poor households, strategically plan for diversifying risks associated with livelihood security. Such mechanisms are a common livelihood strategy in the hill regions. Majority of people have agriculture as the main occupation that includes all land-based activities such as crop farming, horticulture, animal husbandry and forestry carried out in an integrated manner. Agriculture base has been generally at a low or subsistence level employing traditional technology and localised inputs with little output meant for the markets. Employment opportunities outside agriculture sector are limited, and hence, people adopt a variety of coping mechanisms to enhance their income as a livelihood strategy including out-migration.

The most unprotected among the migrant workers are seasonal and short-term migrants who have low endowment base on the one hand and encounter different forms of discrimination in the labour market on the other. More particularly, in the crisis and pandemic situation, they are the worst affected lot due to their nature of jobs and livelihood source which is, in most cases, observed to be temporary and casual. It has been noticed that the majority of return migrants adopted dis-saving their past savings, utilising service pension of family members and dependence on family members (77\%) for survival during these difficult times. Government's help 
through providing ration, cash transfer, etc., has been to the minimal to the return migrants $(10 \%)$. The other mechanism adopted by the migrant workers was dependence on loans from family and friends (9\%), with majority of such loans being extended without any interest. More than one-third of the return igrants reported that they are currently engaged in agriculture (33\%), some in other allied activities such as dairy or animal husbandry $(9 \%)$ and another $6 \%$ engaged in tiny industrial activities. On the other hand, a large proportion of them (48\%) had no work and seeking for the work or unemployed. Only a very small proportion of return migrants $(3.1 \%)$ sought jobs under the Mahatma Gandhi National Rural Employment Guarantee Act (MGNREGA), as the wages fixed under this scheme were low as compared to the prevailing market wages.

\subsection{Plan Ahead}

Majority of the respondents $(68 \%)$ indicated that they would eventually go back to their destinations for earning a livelihood, as there were very few opportunities for livelihoods at their native places. The reasons reported for returning to their destinations were: no employment opportunity in the villages (50\%), followed by a strong desire to return to the existing job/work (36\%), better living standards (19\%), poor health facilities at the native origin (18\%), education of the children (3.1\%), etc.

However, around one-third (32\%) wished to stay back at their native places and desired to engage mainly in farming activities including horticulture (41\%); about one-third $(32.3 \%)$ wanted to work in self-employed non-agriculture activities such as trade/business/tourism; about one-fifth (22\%) preferred to look for salaried jobs; and a small proportion (4\%) were inclined towards casual form of employment such as construction work.

\section{Factors Influencing Out-Migration}

To understand the key factors of out-migration from Uttarakhand, a logistic regression has been carried out, which examines the factors that significantly affect the probability of workers to out-migrate from their native places (see annexure for details). For the regression analysis, HDR-UK survey data have been used, which covered 8500 households in 13 districts of the state. For the logistic regression, the key factors (independent variables) for out-migration includes per capita households income, households size, operational land holdings, caste (SC/ST and otherwise), occupation of the households (casual labour and otherwise), gender (male and otherwise), age, education levels (secondary and above, and otherwise) and districts (plain and hill).

The coefficients of non-labour household income, disadvantaged social group workers, male workers, age and districts (plain and hill) are significant at $1 \%$ level of significance, and age 2 is significant at $10 \%$ level of significance (Table 3). It is important to note that odds ratio for non-labour household income is close to 1 suggesting very small impact on the probability of person to out-migrate. 
Table 3 Results of logistic regression

\begin{tabular}{lll}
\hline Variables & Results & \\
\hline Migrants & Odds ratio & SE \\
Non-labour income & $1.0014 * * *$ & 0.0005 \\
Household size & $1.2144 \#$ & 0.2992 \\
Per capita land & $0.8889 \#$ & 0.1140 \\
ST/ST & $3.2518^{* * * *}$ & 0.7721 \\
Others (OBC/General) & - & - \\
Casual labour HHs & $1.0651 \#$ & 0.2910 \\
Others (regular/self-employed) & - & - \\
Male & $17.8040^{* * *}$ & 4.7856 \\
Female & - & - \\
Age & $0.8531^{* * *}$ & 0.0374 \\
Age2 & $1.0009 *$ & 0.0005 \\
Highly educated (secondary and above) & $1.4568 \#$ & 0.3756 \\
Less educated (below secondary (includ- & - & - \\
$\quad$ ing illiterate) & & \\
Plain districts & $0.2648 * * *$ & 0.0567 \\
Hill districts & - & - \\
Pseudo-R & & \\
\hline
\end{tabular}

Dependent variable is probability of migration among household members; reference categories are italicised

$* * *$ Significant at $1 \%$ level of significance; **significant at $5 \%$ level of significance; *significant at $10 \%$ level of significance; \#insignificant at $10 \%$ level of significance

It is noted that the odds of migration considerably goes up as household size increases. As the per capita land holding increases, odds of migration goes down. It can be inferred that if a household owns sufficient per capita land, probability of migration of its members tends to decline. This has policy implications, particularly for those migrants who own very little land or are landless. Odds of migration in the case of disadvantaged social group workers (SC/ST) is higher than in the case of non-SC and ST workers. For casual-work households, probability of out-migration is significantly higher for all types of migrants.

As age of an individual worker increases by 1 year, odds of migration declines, meaning thereby that migration is more conspicuous among younger age groups than the older age groups. This is evident from the coefficients of age and age 2 that, initially, as age increases by 1 year, odds of migration goes down but after achieving certain age (generally at higher age) odds of migration goes up (albeit, marginally). Such out-migration is primarily motivated by a greater need for social security including health and care at older age. Odds of migration for an educated person (secondary and above) is $45.7 \%$ more than an uneducated worker. The out-migration is male dominated, as odd of migration for male is $178 \%$ higher than for their female counterparts. Finally, we also notice that as one moves from hill to plain districts, odds of migration goes down significantly. This is quite clear and as discussed earlier that due to lack of enough livelihood opportunity and other infrastructural 
facilities people mainly males from hill districts migrate out significantly more than others.

\section{Policy Measures Adopted and the Way Forward}

Out-migration from the hill districts is taking place primarily because of the low economic base, as well as, lack of adequate employment and income earning opportunities. The migration patterns have been changing fast; people are by and large moving out permanently from the villages not only for earning a livelihood but also for better education for their children and availing improved health facilities. This movement is conspicuous from villages to small towns; even block, tehsil and district headquarters are experiencing out-migration. It is also increasingly noted that people are settling in urban locations within the state.

The Uttarakhand government constituted the Palayan Aayog (Migration Commission) in August 2017 for evolving strategies for facilitating faster development of the hill districts and thereby restricting out-migration. Uttarakhand has about 1700 ghost villages, while 1000 hamlets have less than 100 people (Jha and Mishra 2020). However, no visible efforts have been seen to revitalise these villages during the last 3 years since the Commission was constituted. Some district reports have been prepared and survey work undertaken by the Commission, but no action plans have been prepared to create sustainable livelihoods and thus restrict out-migration.

Rural Development and Palayan Aayog have recently completed skill mapping of all the return migrants, and report has been submitted to the Government. It was reported that $58 \%$ of them were engaged in the hospitality and service sectors. Since the focus of government for creating self-employment is on tourism, adventure sports and homestay tourism, this skill mapping will help return migrants to obtain self-employment opportunities in these activities. It was also stated that majority of return migrants $(81 \%)$ arrived from different states, $18 \%$ were from different districts within state, and about $0.3 \%$ were from foreign countries. The government has also included other schemes from different departments to create self-employment opportunities for return migrants. The other promising activities to be included are horticulture, micro-food processing, animal husbandry, poultry, dairying, organic farming, etc. The government has formulated customised scheme for MSMEs and announced loans up to Rs.25 lakh in manufacturing and Rs.10 lakh for services with a provision of $25 \%$ subsidy. Palayan Aayog needs to come out with a detailed rehabilitation plan linking with an actionable economic plan and specific road map for each district. Clearly, the success of Palayan Aayog should be judged in terms of rehabilitation of existing ghost villages by providing sustainable employment.

In the context of the unprecedented COVID-19 pandemic, the plight of migrant workers turned more vulnerable as thousands of migrant workers got stuck in big cities. These migrants had flocked the cities from many states including Uttarakhand in a bid to earn livelihoods. COVID-19 has posed new challenges for mitigation of the hardship of migrant workers. Clearly, there is an urgent need for developing coping mechanisms and strategies for migrants at the place of origin. In this context, the role of Palayan Aayog (Migration Commission) of Uttarakhand Government becomes even 
more important in rehabilitating migrants in their native places by providing them sustainable means of livelihoods.

In the pandemic situation, the return migrants encountered 19 severe disruptions in their livelihood options. The present analysis highlights the precarious situation of migrant workers in Uttarakhand who not only lost their income and sustenance but also faced apathy while desperately trying to flee to their homes in Uttarakhand. Majority of these migrants were engaged in low-paying activities with low earnings or income; most of them were the sole earning member in the families which made them even more vulnerable. Uncertainty looms large for these return migrants, who are unable to sustain livelihoods in their villages.

From the policy point of view, addressing the return migration crisis is a great challenge and also presents an opportunity. Enhancing the economic base and livelihood opportunities by focusing on niche activities, in which the region has comparative advantages, like horticulture, niche products, tourism and amenity services and microhydel plants coupled with improved provisioning of educational and health infrastructure and services, can eventually help restrict out-migration from Uttarakhand. In any case, out-migration is an inevitable process for better education and better employment opportunities, but distress form of out-migration can be restricted by providing better employment and livelihood opportunities including micro-enterprises in which the region has comparative advantages.

\section{Annexure}

The logistic expression is as follows:

$$
\begin{gathered}
y(P)=\frac{1}{1+e^{-z}} \\
z=\beta_{0}+\beta_{1} x_{1}+\beta_{2} x_{2}+\beta_{3} x_{3}+\beta_{4} x_{4}+\beta_{5} x_{5}+\beta_{6} x_{6}+\beta_{7} x_{7}+\beta_{8} x_{8}+\beta_{9} x_{9}+\beta_{10} x_{10+\mu}
\end{gathered}
$$

where $z=$ status of out-migration; $x_{1}=$ per capita household income $(y) ; x_{2}=\log$ of household size (lnhhsz); $x_{3}=\log$ of per capita land in acre (lnpcland); $x_{4}=$ caste of a worker (dummy, if SC, ST and others $=1$, otherwise $=0)$ (dcaste); $x_{5}=$ casual labour (dummy, if household belongs to casual labour household $=1$, otherwise $=0$ ) $\left(\right.$ caslab); $x_{6}=$ male $($ dummy, if male $=1$ otherwise $=0)($ male $) ; x_{7}=$ age in completed years (age); $x_{8}=$ age square (age 2 ); $x_{9}=$ educated (dummy, if educated higher secondary and above $=1$ non-educated $=0$ ) (educated); $x_{11}=$ districts (dummy, if plains $=1$ otherwise $=0) ; \mu=$ stochastic error term.

However, using a simple logistic model may lead to biased estimates of explanatory variable, viz. income, because of endogeneity between the income and probability of migration. This essentially implies that the said two variables are mutually determined by each other in the shape of the simultaneous equation model.

The exact functional form takes the form of simultaneous equation as follows:

$$
P(M)=\beta_{0}+\beta_{1} x+\beta_{2} x_{1}+\beta_{3} x_{2}+\beta_{4} x_{3}+\cdots+\mu
$$




$$
Y=\alpha_{0+} \alpha_{1} M+\alpha_{2} x_{1+} \alpha_{3+} x_{2+} \alpha_{4} x_{3}+\cdots+\Omega
$$

In order to correct the endogeneity problem, 2-stage least square (2SLS) model has been used. Under the 2SLS, income $(Y)$ variable is first regressed upon exogenous variable, viz. non-labour income and asset-holding and other control variables. ${ }^{2}$

$$
y=f(\text { nlab in, asset, control) }
$$

The predicted value of y has been used in the logistic model. Hence, the logistic model becomes

$$
P(M)=\beta_{0}+\beta \hat{y} \beta_{1} x_{1}+\beta_{2} x_{2}+\beta_{3} x_{3}+\beta_{4} x_{4}+\cdots \beta_{n} x_{n}
$$

where $\hat{y}$ is predicted value of $\mathrm{y}$ (income of households) and $x_{1}, x_{2}, \ldots x_{n}$ are control variables.

This is quite plausible in the poor households with higher dependency ratio that in turn pushes the able-bodied male members to out-migrate in search of jobs and livelihoods. This is more in the case of long-term migrants who are the most vulnerable lots, which is 23 times greater as compared to non-casual labour households. Similarly, the odds of migration for male workers is much higher as compared to female workers.

\section{References}

Awasthi, I.C. 2010. Migration Patterns in Hill Economy of Uttarakhand: Evidence from Field Enquiry. Indian Economic Journal 57 (4): 84-99.

Awasthi, I.C. 2012. Livelihood Diversities in Mountain Economy, Constraints and Opportunities. New Delhi: Concept Publishing Company.

Bora, R.S. 1986. Extent and Causes of Migration from the Hill Region of Uttar Pradesh. In Migrant Labour and Related Issues, ed. Vidyut Joshi. New Delhi: Oxford \& IBH Publishing Company.

Bora, R.S. 1996. Himalayan Migration: A Study of the Hill Region of U.P.. New Delhi: Sage Publication.

Brigitte, H., and K. Michael. 2009. Labour Migration and Remittances in the Hindu Kush-Himalayan Region. ICIMOD Working Paper, International Centre for Integrated Mountain Development, Kathmandu, Nepal.

Davies, S. 1996. Adaptable Livelihoods: Coping with Food Insecurity in the Malian Sahel. London: Macmillan Press.

De Haan, Arjan. 1999. Livelihoods and Poverty: The Role of Migration-A Critical Review of the Migration Literature. The Journal of Development Studies 36 (2): 1-47.

de Haas, Hein. 2008. Migration and Development: A Theoretical Perspective. Working Papers, Paper 9, International Migration Institute, James Martin 21st Century School, University of Oxford.

Duraisamy, P. 2000. Changes in Returns to Education in India, 1983-94: By Gender Age Cohort and Location. Centre Discussion Paper No. 815. Economic Growth Centre, Yale University.

Ellis, F. 2000. Rural Livelihoods and Diversity in Developing Countries. Oxford: Oxford University Press.

Government of Uttarakhand. 2019-20. Press Note on Provisional (Second Revised) Estimates, Year 2018-19 of State Domestic Product Uttarakhand.

\footnotetext{
${ }^{2}$ Non-labour income has been used as an alternate instrumental variable which is well recognised in the literature (Duraisamy 2000).
} 
Harris, J. 1991. Agriculture and Non-Agriculture Linkages and the Diversification of Rural Economic Activities: A South Indian Case Study in Rural Transformation in Asia. Delhi: Oxford University Press.

Human Development Report-Uttarakhand. 2019. Institute for Human Development, Delhi.

Indian Express, June 8, 2020. Retrieved from, https://indianexpress.com/article/explained/coronaviru s-how-many-migrant-workers-displaced-a-range-of-estimates-6447840/.

International Centre for Integrated Mountain Development, (ICIMOD). 2011. Labour Migration and Remittances in Uttarakhand. Case Study Report. Kathmandu: ICIMOD.

International Centre for Integrated Mountain Development, (ICIMOD). 2017. De-Population Trends, Patterns and Effects in Uttarakhand, India-A Gateway to Kailash Mansarovar. ICIMOD Working 2017/22.

Ioannides, Y.M., and L. Datcher Loury. 2004. Job Information Networks, Neighborhood Effects and Inequality. Journal of Economic Literature 42: 1056-1093.

Jha, Prashant and Ishita Mishra. 2020. Uttarakhand's Ghost Villages' Spring Back to Life, Times of India City, June 17.

Khanka, S.S. 1988. Labour Force, Employment and Unemployment in a Backward Economy. New Delhi: Himalaya Publishing House.

Lipton, M. 1980. Migration from Rural Areas of Poor Countries: The Impact on Rural Productivity and Income Distribution. World Development 8: 1-24.

Maithani, B.P. 1996. Towards Sustainable Hill Area Development, Himalaya. Man, Nature and Culture 16 (2): 4-7.

Mamgain, R.P., and D.N. Reddy. 2015. Outmigration from Hill Region of Uttarakhand, Magnitude, Challenges and Policy Options. Project Report, National Institute of Rural Development, Hyderabad.

Mitra, A. 2004. Informal Sector, Networks and Intra-City Variations in Activities: Findings from Delhi Slums. Review of Urban and Regional Development Studies 16 (2): 154-169.

Mitra, A. 2010. Migration, Livelihood and Well-being: Evidence from Indian City Slums. Urban Studies 47 (7): 1371-1390.

NSSO. 2019. Unit Level Records of Periodic Labour Force Survey, 2017-18. New Delhi: Government of India.

Portes, A. 1998. Social Capital: Its Origins and Applications in Modern Sociology. Annual Review of Sociology 24: 1-24.

Srivastava, Ravi. 2019. Emerging Dynamics of Labour Market Inequality in India: Migration, Informality, Segmentation and Social Discrimination. The Indian Journal of Labour Economics 62: $147-171$.

Stark, Oded. 1980. On the Role of Urban-Rural Remittances in Rural Development. The Journal of Development Studies 16 (3): 324-341.

Stark, Oded. 1991. The Migration of Labour. Cambridge, MA: Harvard University Press.

Stark, Oded. 1995. Altruism and Beyond: An Economic Analysis of Transfers and Exchanges within Families and Groups. Cambridge: Cambridge University Press.

Todaro, M.P. 1969. A Model of Labour Migration and Urban Unemployment in Less Developing Countries. The American Economic Review 59 (1): 138-148.

Uttarakhand Government. 2019. Rural Development and Migration Commission, Uttarakhand, Report. Retrieved Sept 5, 2020 from, http://www.spc.uk.gov.in/upload/contents/File-98.pdf.

Publisher's Note Springer Nature remains neutral with regard to jurisdictional claims in published maps and institutional affiliations.

\section{Affiliations}

\section{Ishwar Awasthi ${ }^{1} \cdot$ Balwant Singh Mehta ${ }^{1}$}

Balwant Singh Mehta

balwant.mehta@ihdindia.org

1 Institute for Human Development, Delhi, India 